\title{
携帯機器用アンダーフィル実装試験片の強度評価
}

\author{
矢口 昭弘 ${ }^{*}$, 中村 真人 ${ }^{* *}$, 石川 高司 ${ }^{* * *}$, 黒沢 和仁 ${ }^{* * *}$, 木本 良輔 ${ }^{* * * *}$
}

\section{Strength Evaluation of Specimens Mounted with Underfill Resins in Mobile Apparatus}

Akihiro YAGUCHI*, Masato NAKAMURA ${ }^{* *}$, Takashi ISHIKAWA ${ }^{* * *}$, Kazuhito KUROSAWA ${ }^{* * *}$ and Ryosuke KIMOTO****

*株式会社日立製作所機械研究所（广 300-0013 茨城県土浦市神立町 502）

**株式会社日立製作所生産技術研究所（２２44-0817 神奈川県横浜市戸塚区吉田町 292）

***株式会社カシオ日立モバイルコミュニケーションズ（テ207-8501 東京都東大和市桜ヶ丘2-229）

****株式会社ルネサステクノロジ生産本部（テ 187-8588 東京都小平市上水本町 5-20-1）

* Mechanical Engineering Research Laboratory, Hitachi, Ltd. (502 Kandatsu-machi, Tsuchiura-shi, Ibaraki 300-0013)

**Production Engineering Research Laboratory, Hitachi, Ltd. (292 Yoshida-cho, Totsuka-ku, Yokohama-shi, Kanagawa 244-0817)

***Casio Hitachi Mobile Communications Co., Ltd. (2-229 Sakuragaoka, Higashiyamato-shi, Tokyo 207-8501)

****Production and Technology Unit, Renesas Technology Corp. (5-20-1 Josuihoncho, Kodaira-shi, Tokyo 187-8588)

概要＼cjkstart携帯機器用BGA パッケージのはんだ接続部強度向上に適したアンダーフィル実装構造確立のため, 機械的負荷や熱 疲労に対するはんだ接続部強度に，樹脂物性や塗布形状が及ぼす影響を実験と有限要素解析を比較して検討した。機械的負荷 に対するはんだ接続部の断線強度は樹脂塗布によって塗布無し品より高くなるが, 高弹性樹脂では, 樹脂割れに対する強度が 低下する場合がある。アンダーフィル樹脂の線膨張係数がはんだ材の約 2 倍であるため, 温度サイクル寿命は塗布無し品より 短くなった。樹脂割れも考慮した機械的強度の向上には, フィレット形成と樹脂弾性率の適正化が必要であり, 温度サイクル 寿命の向上には，樹脂の線膨張係数をはんだの值に近づけるのが有効である。

\begin{abstract}
The purpose of this study is development of a mounting structure to improve the strength of solder joints for portable devices. In this paper, the strengths of solder joints in chip-scale packages reinforced with various under-fill resins were determined by static-bending, cyclic-bending, impactbending, and heat-cycle tests. Joint strength during static, cyclic, and impact-bending was improved by reinforcing with resins. The lifetimes in heat-cycle tests $\left(-40^{\circ} \mathrm{C} / 85^{\circ} \mathrm{C}\right)$ were increased 1000 times or more. It was found that the shape of the resin fillets and the elastic modulus of the resin must be optimized to further increase the strength.
\end{abstract}

Key Words: Ball Grid Array, Solder Bump Joints, Bending Test, Impact Bending Test, Heat Cycle Test, Surface Strain, Under-Fill, FEM

\section{1. 緒 言}

携帯機器の小型・軽量化および多機能化に対応するた め, 搭載される半導体パッケージも小型化が進んでいる。 半導体パッケージの実装には微小な BGA (Ball Grid Array) はんだボールが用いられる場合が多く，このはんだ接続部 には外部からの衝撃や曲げなど機械的負荷に対する強度向 上が要求されている。はんだ接続部の強度向上の一手段と して, パッケージと実装基板の間にアンダーフィル樹脂を 塗布する場合がある。アンダーフィル樹脂によるはんだ接 続部の補強に関しては, 温度変化に対する信頼性向上を目 的として, 機械的物性および塗布形状の適正化を検討した

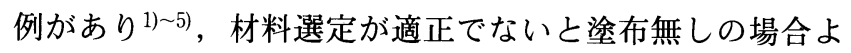
り温度サイクル寿命が低下するとの報告 ${ }^{1)}$ がある。同様に 機械的負荷に関してもアンダーフィル樹脂の機械的物性や 塗布形状を適正化しないと十分な強度向上の効果が得られ ないと考えられるが，衝撃や曲げなどの負荷に対するアン
ダーフィル実装の信頼性評価はほとんど実施されていな (6)。したがって, アンダーフィル樹脂を塗布したパッケー ジ基板実装品の強度信頼性を向上させるためには, 衝撃や 曲げを負荷した場合における樹脂物性や塗布形状の強度へ の影響を把握し, 実装設計に反映させることが不可欠であ る。

そこで本研究では, 携帯機器に要求される機械的負荷に 対する接続部強度に関して, アンダーフィル樹脂物性や塗 布形状が及ぼす影響を実験的に求め, 有限要素解析結果と 比較することにより, 強度向上に適した実装構造を検討し た。また，温度サイクル寿命に対する樹脂物性の影響につ いても検討した。

\section{2. 供試材および実験方法}

\section{1 供試材}

実験に用いたアンダーフィル樹脂は, Table 1 に示す 2 種 類の材料である。Table 1 に示した物性值はメーカカタログ 
Table 1. Material properties of under-fill resins

\begin{tabular}{|c|c|c|c|c|}
\hline \multirow{2}{*}{ Material } & \multirow{2}{*}{$\begin{array}{c}\text { Young's } \\
\text { Modulus } \\
(\mathrm{MPa})\end{array}$} & \multicolumn{2}{|c|}{$\begin{array}{c}\text { Coefficient of Thermal } \\
\text { Expansion }\left(10^{-6} /{ }^{\circ} \mathrm{C}\right)\end{array}$} & \multirow{2}{*}{$\begin{array}{c}\text { Glass } \\
\text { Transition } \\
\text { Temperature } \\
\left({ }^{\circ} \mathrm{C}\right)\end{array}$} \\
\hline & & $\alpha_{1}$ & $\alpha_{2}$ & \\
\hline $\mathrm{A}$ & 790 & 60 & 180 & 145 \\
\hline B & 2800 & 57 & 170 & 140 \\
\hline
\end{tabular}

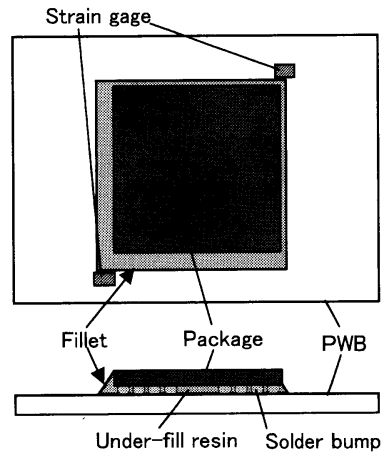

(a) Two side coating

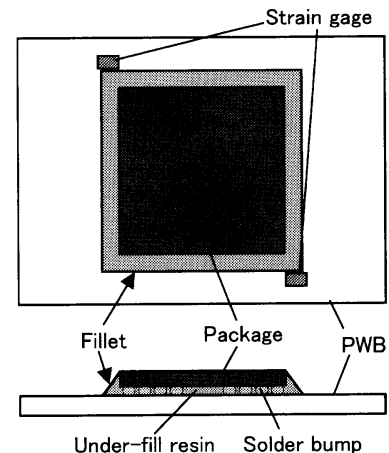

(b) Four side coating
Fig. 1 Shape of under-fill resins

值である。また実験には, Fig. 1 に示すアンダーフィル樹 脂の塗布状態が異なる 2 種類の実装試験片を用いた。1つ は，(a)に示すようにパッケージの連続した 2 辺から塗布し てパッケージと実装基板の間に樹脂を流入させた形状であ り，2辺塗布品と称する。2辺塗布品では, 樹脂塗布して いない側ではフィレットが小さくなっている。もう1つは, フィレット大小の影響を検討するため, 2 辺塗布品に追加 で樹脂塗布を行い，(b)のように 4 辺すべてに大きなフィ レットを形成した形状であり，4辺塗布品と称する。アン ダーフィル樹脂の硬化条件は, 両材料とも温度 $120^{\circ} \mathrm{C}$, 時 間 60 分とした。

実装したパッケージは, 外形 $10 \mathrm{~mm} \times 10 \mathrm{~mm} \times 0.9 \mathrm{~mm}$ 厚, バンプピッチ $0.5 \mathrm{~mm}$ ，搭載ボールサイズ $\phi 0.5 \mathrm{~mm}$ の 225 ピ ン CSP (Chip Scale Package)であり，はんだ材は Sn-3Ag$0.5 \mathrm{Cu}$ とした。実装基板は $50 \mathrm{~mm} \times 100 \mathrm{~mm} \times 0.8 \mathrm{~mm}$ 厚の FR4 相当基板とした。はんだ接続部は，パッケージ側，実装 基板側ともにSMD (Solder Mask Defined) 構造とした。

\section{2 実験方法}

Fig. 2 に示す静的 3 点曲げを用い，試験片に静的に曲げ負 荷を与えてはんだ接続部の断線強度を測定した。支点間の スパンは $50 \mathrm{~mm}$ であり, パッケージ実装面を下向きして支 点上に設置し, 螴面側から負荷を加えた。クロスヘッド速 度は $6 \mathrm{~mm} / \mathrm{min}$ とした。

一定荷重を繰り返し与えて疲労寿命を測定する繰り返し 曲げ試験も静的曲げ試験と同様, Fig. 2 に示した 3 点曲げ試 験で行った。繰り返し周波数は $0.1 \sim 0.3 \mathrm{~Hz}$ （クロスヘッド 速度は30 60 mm/min）である。

衝撃曲げ試験7) 9) では, Fig. 3 に示すようにパッケージ実 装面を下向きに固定し, パッケージ実装部分の裏面に落下

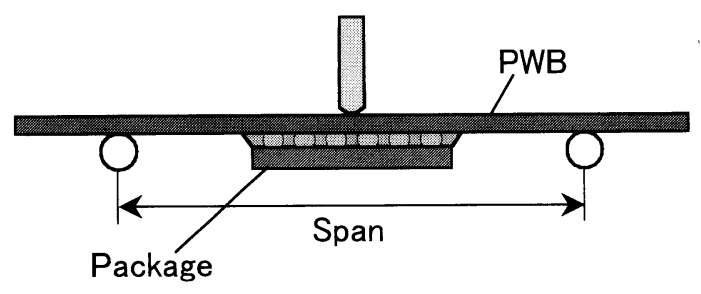

Fig. 2 Outline of bending test

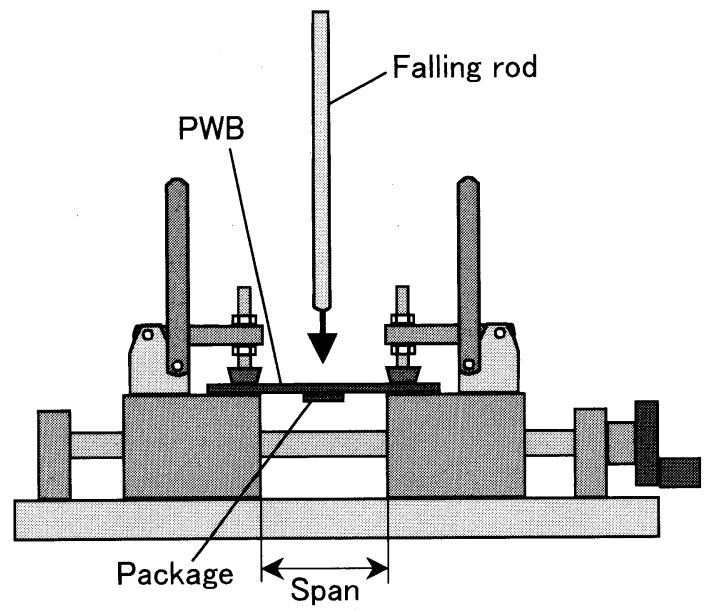

Fig. 3 Outline of impact bending test

ロッドを繰り返し衝突させ，はんだ接続部が断線するまで の衝撃回数を測定した。試験片の固定スパンは $60 \mathrm{~mm}$ とし た。

上記した静的曲げ，繰り返し曲げおよび衝撃曲げの各機 械的負荷試験では，Fig. 1 中に併せて示すように，実装基 板表面のパッケージコーナー近傍にひずみゲージ（グリッ ド長 $1 \mathrm{~mm}$ ）を貼り付け，基板表面ひずみを測定した。塗 布無し品ではパッケージコーナー1個所, 樹脂塗布品は, 対角コーナー2箇所で基板ひずみを測定した。はんだ接続 部の断線発生は，パッケージと実装基板のはんだ接続部を 直列に連結した回路（デイジーチェーン）の抵抗または導 通電圧を測定して判定した ${ }^{10)}$ 。

温度サイクル試験は, $\mathrm{A}$ 材, $\mathrm{B}$ 材の 2 辺塗布品と樹脂塗 布無し品を用いて, $-40^{\circ} \mathrm{C} / 85^{\circ} \mathrm{C}, 1$ サイクル $20 \min ($ 低温 $10 \mathrm{~min} /$ 高温 $10 \mathrm{~min}$ ）の条件で行った。サンプル数は各仕様 5 個である。はんだ接続部の断線は, 所定の回数ごとに試 験槽から試験片を取り出し, 室温でのはんだ接続部抵抗を 測定して判断した。また，温度サイクル試験中の温度とは んだ接続部抵抗の挙動を観察するため, $-55^{\circ} \mathrm{C} / 125^{\circ} \mathrm{C}, 1$ サ イクル $60 \mathrm{~min}$ （サンプル数各仕様 3 個）の温度サイクル試 験中の抵抗を連続的に測定する実験む行った。

\section{3. 実験結果}

\section{1 静的曲げ試験結果}

$\mathrm{A}$ 材 -2 辺塗布品の静的曲げ試験の変位量に対する基板 表面ひずみと導通電圧の挙動を Fig. 4 に示す。フィレット 


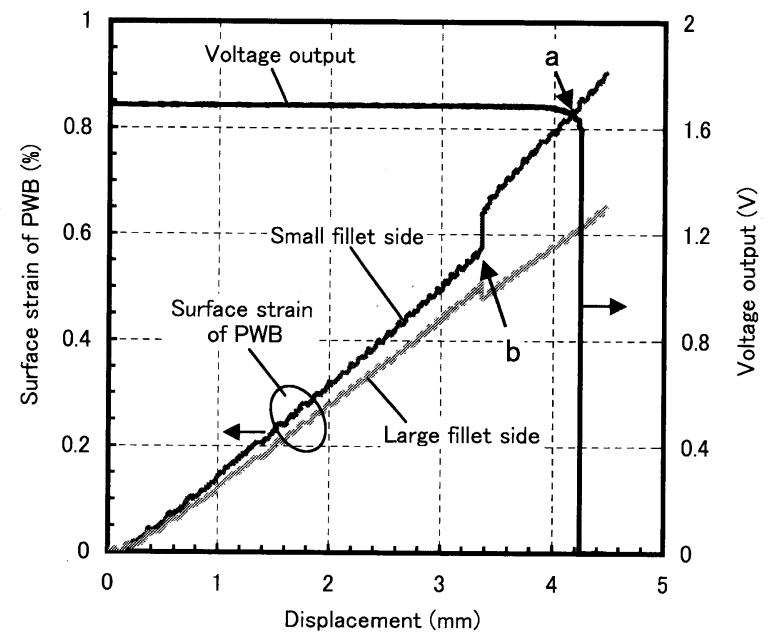

Fig. 4 Measurement results of static-bending test

が小さい側のコーナーに発生する基板ひずみが，フィレッ トが大きい側より高くなっており，フィレットが小さい側 の実装基板の変形が大きくなることを示している。導通電 圧を示す曲線には, 電圧が急激に低下する挙動が見られ, この時点（Fig. 4 中 a 点）で, はんだ接続部に断線が発生 したと判断した。Fig. 4 の曲線には, 断線発生前に図中b点 のような基板ひずみの急増点が現れており，このb点では， アンダーフィル樹脂に割れが発生していることを確認して いる。b点では，アンダーフィル樹脂が割れるのに伴って 樹脂で抑えられていた実装基板の変形が解放されるため, 基板ひずみが増加する。この樹脂割れは， $\mathrm{A}$ 材 -4 辺塗布品 および $\mathrm{B}$ 材でも同様に発生した。樹脂塗布無し品では $\mathrm{b}$ 点 のような変曲点は見られず，Fig. 4 の 点のように導通電圧 が急激に低下し，はんだ接続部に断線が発生する。

樹脂割れとはんだ接続部断線発生時の荷重と基板ひずみ それぞれの值を，各実装仕様についてプロットした結果を Fig. 5, Fig. 6 に示す。樹脂塗布品のはんだ接続部断線時の 各測定結果は, 塗布無し品よりばらつきが大きくなってい る。樹脂塗布品の断線発生荷重および基板ひずみは, 塗布 無し品より増加しており，荷重および基板ひずみのいずれ 屯 $\mathrm{A}$ 材 -2 辺塗布, $\mathrm{A}$ 材 -4 辺塗布, $\mathrm{B}$ 材 -2 辺塗布の順に強 度が高くなっている。一方, 叙布形状の違いによる樹脂割 れ強度は, 荷重で見ると4辺塗布が高くなるが，基板ひず みでは塗布形状による差異はほとんど見られない。A材と $\mathrm{B}$ 材を比較すると, 荷重, 基板ひずみのどちらも $\mathrm{B}$ 材が高 くなっている。また，樹脂割れは，塗布無し品のはんだ接 続部断線発生より低い荷重, 低い基板ひずみで発生する可 能性があることがわかる。

$\mathrm{A}$ 材 -2 辺塗布品抢よび $\mathrm{B}$ 材 -2 辺塗布品で，クロスヘッ ド速度 $60 \mathrm{~mm} / \mathrm{min} て ゙$ 曲げ試験を行い，Fig. 5 に示した $6 \mathrm{~mm} / \mathrm{min}$ の曲げ試験と比較した結果を Fig. 7, Fig. 8 に示す。 Fig. 7 に示した A 材は，負荷速度が変わっても樹脂割れ荷 重, 断線発生荷重ともにほぼ一定となっているが, Fig. 8

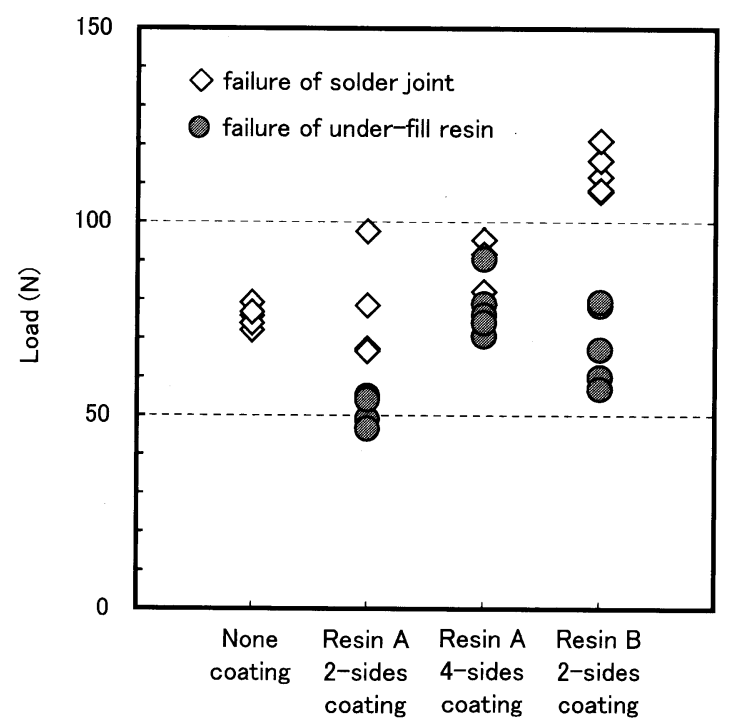

Fig. 5 Failure load of solder joints and under-fill resins with static bending test

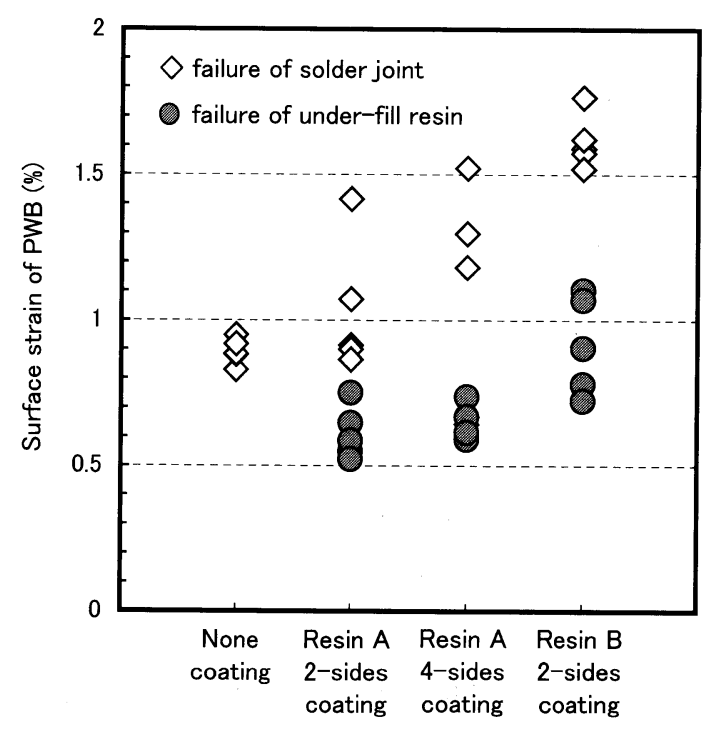

Fig. 6 Failure strain of solder joints and under-fill resins with static bending test

のB材は，負荷速度の上昇に伴って樹脂割れ荷重，断線発 生荷重ともに低下しており，負荷速度の依存性が現れてい る。また, 負荷速度が速い場合の B材の樹脂割れ荷重は, $\mathrm{A}$ 材より低くなっている。

Fig. 9 は, A 材 -4 辺塗布品の静的曲げ試験を行った試験 片のはんだ接続部断面観察写真である。観察した断面位置 は最外周列にあるバンプである。パッケージコーナー部分 の Aバンプとその隣のBバンプに断線が発生しており, フィレット表面上端部から発生したき裂が実装基板方向へ 進展し，このき裂が進展した A バンプでは実装基板側接続 部の接続界面近傍で断線している。樹脂のき裂が達してい ないBバンプでははんだ母材の破壊が発生している。なお, 樹脂塗布品の断面の破壊状態は, $\mathrm{A}$ 材 -2 辺塗布および $\mathrm{B}$ 材 -2 辺塗布品でもほぼ同じであるが，2辺塗布品ではフィ 


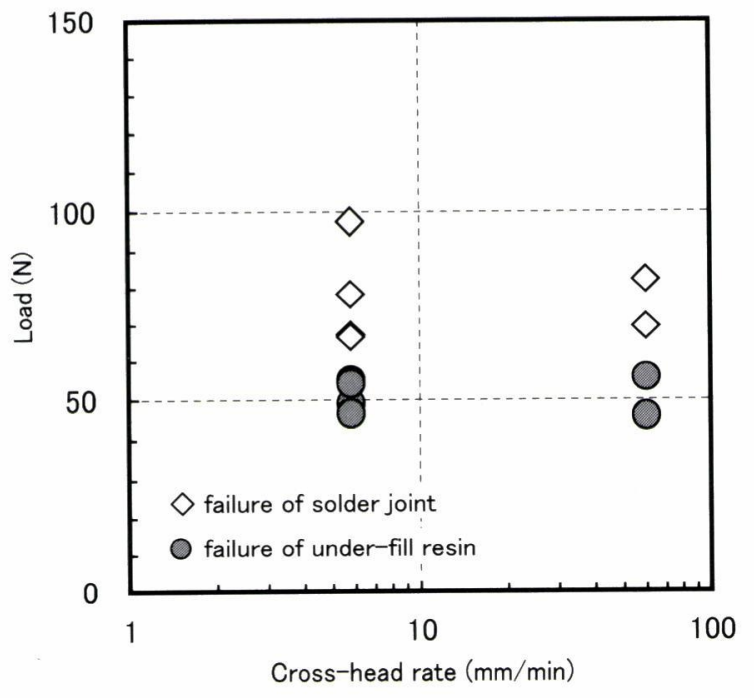

Fig. 7 Relationship between failure load and cross-head rate (Resin A)

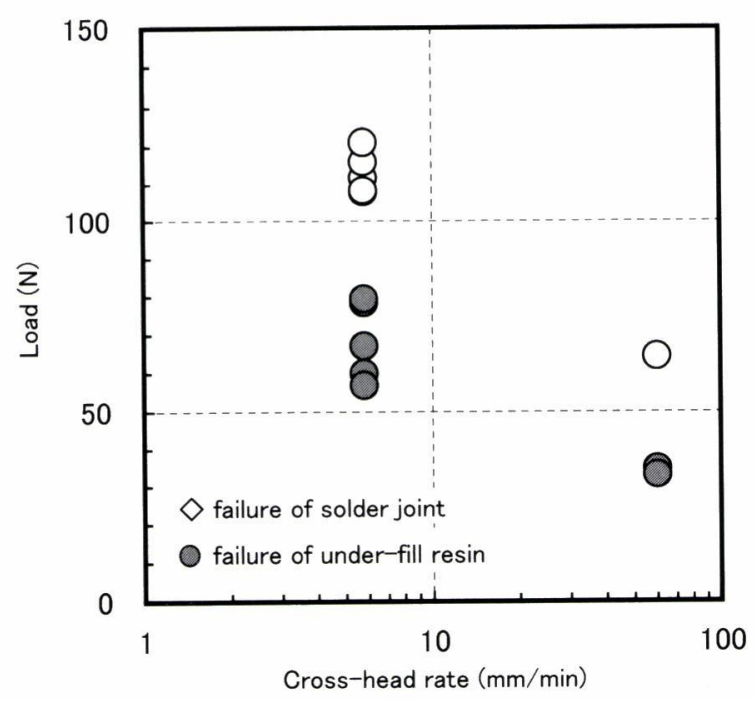

Fig. 8 Relationship between failure load and cross-head rate (Resin B)

レットの小さい側で樹脂割れとはんだ接続部の断線が発生 していた。また，はんだバンプの実装基板側接続部近傍に は，A材，B材いずれの場合もアンダーフィル樹脂の未充 てんが発生していた。

\section{2 繰り返し曲げ試験結果}

$\mathrm{A}$ 材 -2 辺塗布品の基板表面ひずみと導通電圧の挙動を Fig. 10に示す。Fig. 10に示した基板表面ひずみはアンダー フィル樹脂のフィレットが小さい側の測定値である。繰り 返し曲げでは, はんだ接続部の抵抗と固定抵抗を直列に連 結した回路に電圧を加え, 固定抵抗部の電圧を測定して断 線発生を判断した。はんだ接続部の抵抗が初期值の 2 倍に なると, 固定抵抗部の電圧が初期值に対して約 $10 \%$ 低下す るため, この電圧 $10 \%$ 低下時点を断線と定義し, Fig. 10 で は図中に示す $\mathrm{a}$ 点を断線寿命とした。断線発生前には図中 $\mathrm{b}$ 点のような基板ひずみの急増が見られ, 静的曲げと同様

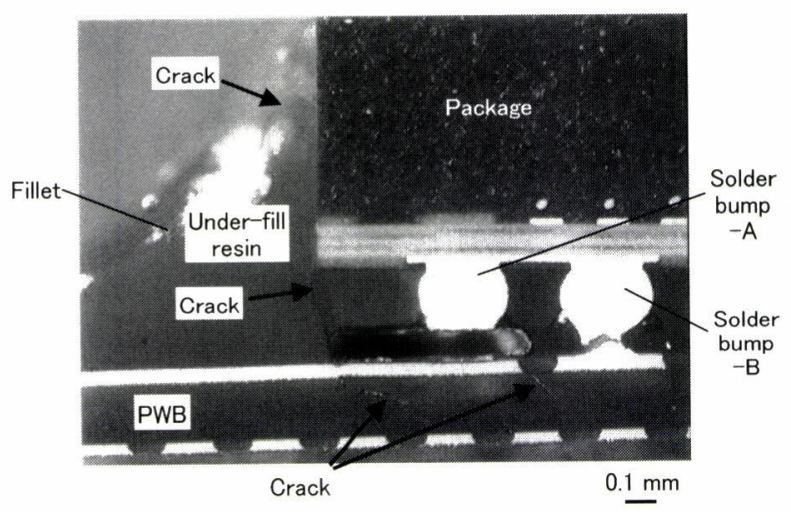

Fig. 9 Cross section of solder joint after static bending test

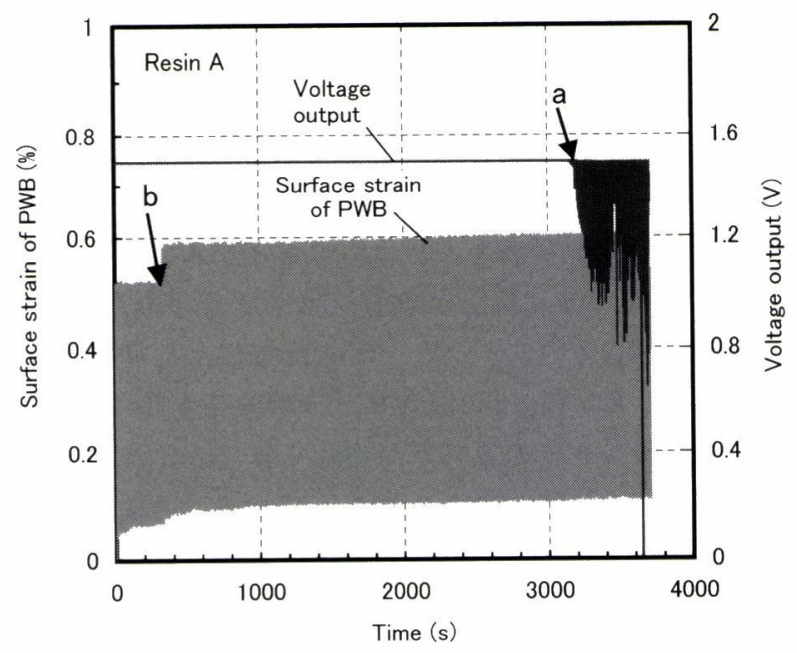

Fig. 10 Measurement results of cyclic-bending test

にアンダーフィル樹脂に割れが発生した。なお，フィレッ トが大きい側では基板ひずみの急増は見られず， 2 辺塗布 品での樹脂割れはフィレットの小さい側で発生した。断線 発生前の樹脂割れは $\mathrm{A}$ 材 -4 辺塗布品および $\mathrm{B}$ 材でも発生

していた。

荷重振幅とはんだ接続部の断線発生寿命の関係を Fig. 11 に, 樹脂割れ発生寿命との関係をFig. 12 に示す。本試験で は，上記したように試験途中で樹脂割れが発生して基板ひ ずみが変動するため, 基板ひずみによる寿命の整理は実施 していない。Fig. 11 に示すように樹脂塗布品の断線発生寿 命は塗布無し品より長くなり, $\mathrm{A}$ 材, B 材間の断線発生寿 命の差はほとんど見られないが, 2 辺塗布より 4 辺塗布が 高寿命であることがわかる。Fig. 12 に示した樹脂割れの寿 命に関してはB材が短く, 本試験範囲では 10 回以下で樹脂 割れが発生した。4辺塗布品は, 樹脂割れ寿命も 2 辺塗布 品より長くなっている。また, 2 辺塗布品の樹脂割れ寿命 は, Fig. 12 に併せてプロットした樹脂塗布無しの断線寿命 より短くなる場合が見られている。Fig. 11 に示した接続部 断線寿命と荷重の関係は, 樹脂塗布無し品がほぼ1本の線 上にプロットされるのに対して, 樹脂塗布品は静的曲げ試 


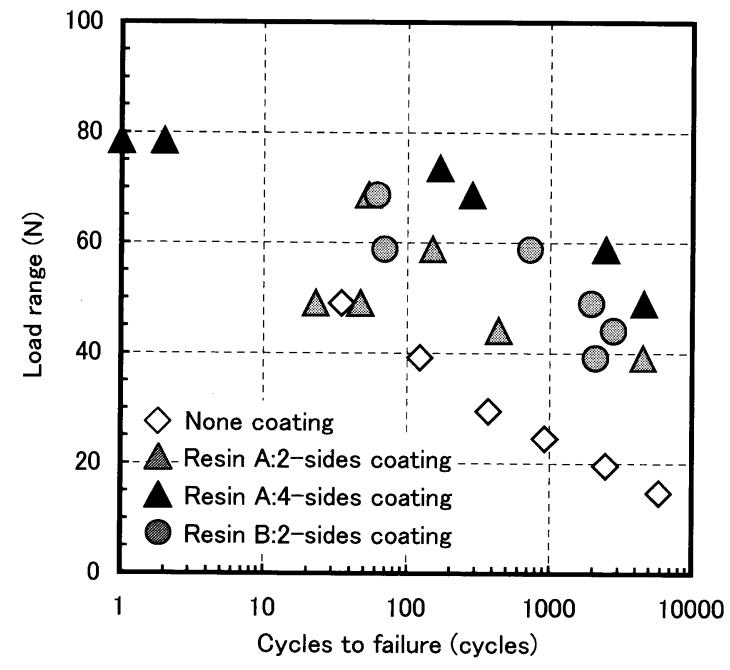

Fig. 11 Relationship between load range and bending fatigue life of solder joints

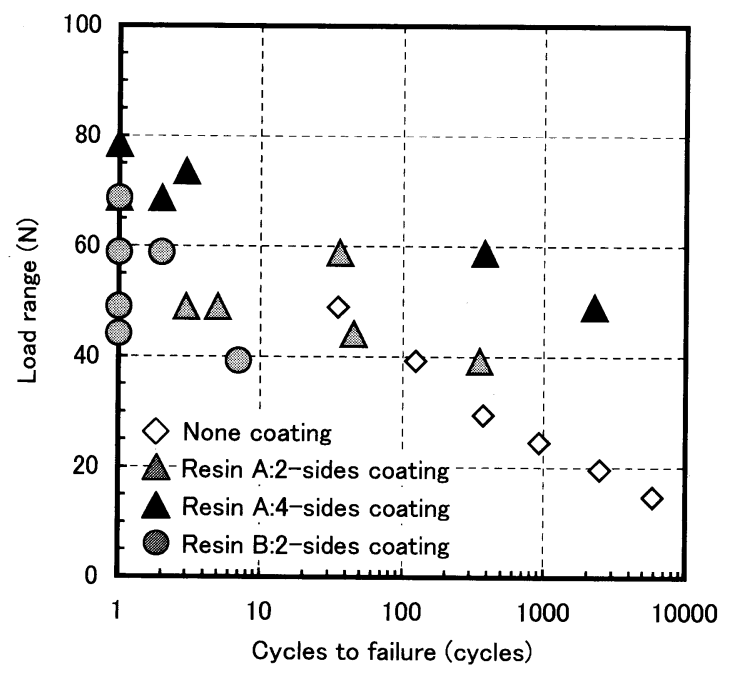

Fig. 12 Relationship between load range and bending fracture life of resin

験と同様にばらつきが大きくなっている。

繰り返し曲げ試験片の破壊は, 静的曲げ試験と同様に, アンダーフィル樹脂に発生したき裂が実装基板側の接続部 方向へ進展し，はんだ接続部の断線はパッケージコーナー 部バンプの実装基板側接続部で発生していた。樹脂割れの 先端がはんだ接続部に達している場合は, Fig. 9 のAバン プのように接続界面近傍をき裂が進展して断線していた。 また, 樹脂割れが接続部から離れたところへ進展し, 実装 基板割れに至るような場合には，Fig. 9 のBバンプのよう にはんだ母材をき裂が進展する破壊も発生していた。

\section{3 衝撃曲げ試験結果}

衝撃負荷回数と測定した基板ひずみの関係を Fig. 13 に示 す。この試験片の断線発生寿命は79回である。試験初期 には, フィレットの小さい側の基板ひずみが大きくなって いるが, フィレットの大きい側の曲線に, 図中 $\mathrm{a}$ 点で示す 基板ひずみの急増が現れている。この点でアンダーフィル

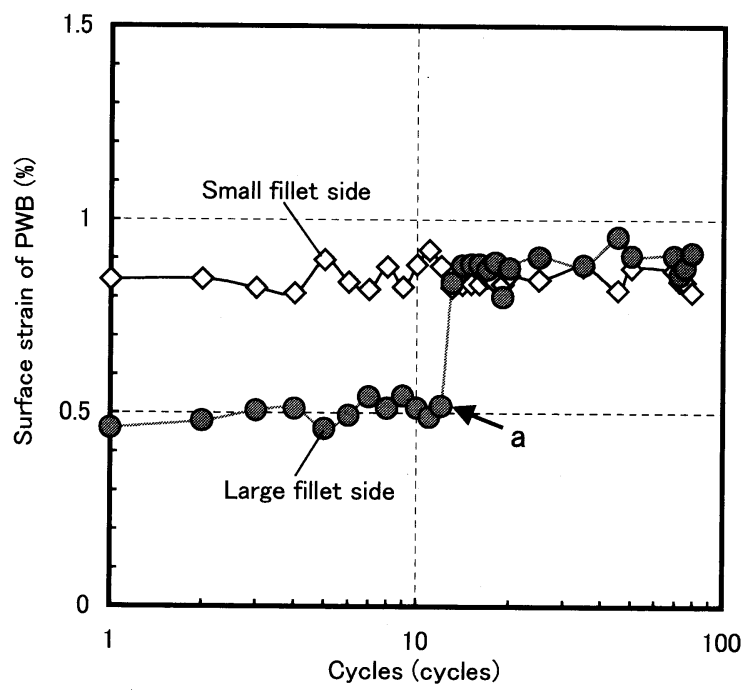

Fig. 13 Measurement results of impact-bending test

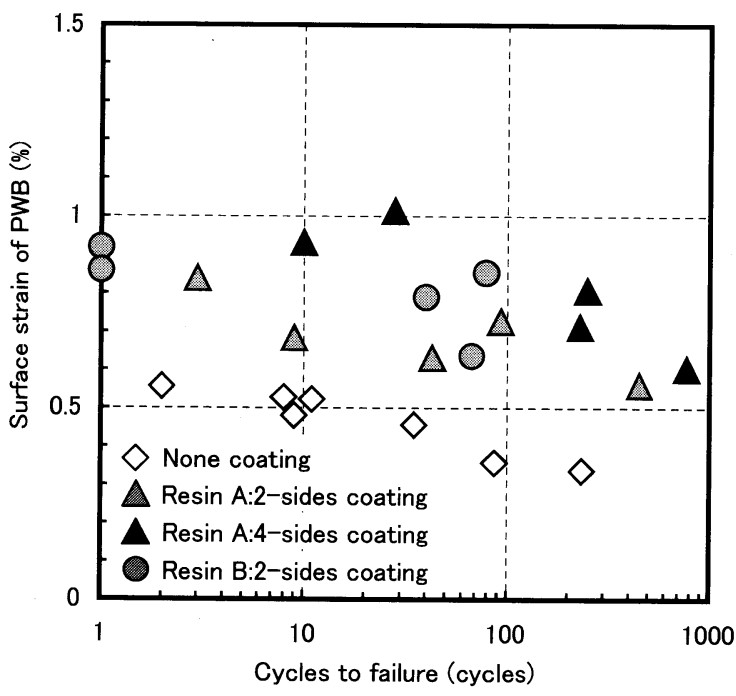

Fig. 14 Relationship between strain of PWB and cycles to failure of solder joints

樹脂の割れが発生していることを目視で確認した。負荷が 小さい場合では，断線発生前に基板ひずみが増加する傾向 は認められたが，Fig. 13のa点のような樹脂割れによる明 確なひずみ急増が現れない場合もあった。衝撃曲げ試験で は，基板ひずみの変動が明確に検知できなかったので，樹 脂割れ発生寿命は測定できなかった。また， 2 辺塗布品で はフィレットの大きい側で樹脂割れが発生する場合があり， フィレットの小さい側で樹脂割れが発生した静的曲げや繰 り返し曲げとは挙動が異なっていた。

Fig. 14 には，基板ひずみとはんだ接続部の断線寿命の関 係を示す。断線寿命は，接続部抵抗が初期值に対して 2 倍 以上になった時点と定義した。また，樹脂塗布品の基板ひ ずみの值には，2 箇所で測定した基板ひずみのうち大きい 側の測定值を用い，回数 20 回まで，もしくは樹脂割れ発生 前までの平均值とした。Fig. 14 より，樹脂塗布品の断線寿 命は, 塗布無し品より 1 桁以上長くなっており, 樹脂塗布 
Table 2. Number of failed specimens after -40 to $85^{\circ} \mathrm{C}$ temperature cyclic test

\begin{tabular}{c|c|c|c|c|c|c|c|c|c|c}
\hline \multirow{2}{*}{ Underfill } & \multicolumn{10}{c}{ Number of temperature cycles (cycles) } \\
\cline { 2 - 11 } & 210 & 315 & 525 & 855 & 1050 & 1470 & 1635 & 1800 & 2200 & 3000 \\
\hline $\mathrm{A}$ & $0 / 5$ & $0 / 5$ & $0 / 5$ & $0 / 5$ & $0 / 5$ & $0 / 5$ & $0 / 5$ & $1 / 5$ & $0 / 4$ & $0 / 4$ \\
\hline $\mathrm{B}$ & $0 / 5$ & $0 / 5$ & $0 / 5$ & $0 / 5$ & $1 / 5$ & $3 / 5$ & $3 / 5$ & $4 / 5$ & $5 / 5$ & - \\
\hline None & $0 / 5$ & $0 / 5$ & $0 / 5$ & $0 / 5$ & $0 / 5$ & $0 / 5$ & $0 / 5$ & $0 / 5$ & $0 / 5$ & $0 / 5$ \\
\hline
\end{tabular}

による耐衝撃性向上が明らかに見られる。 $\mathrm{A}$ 材， $\mathrm{B}$ 材間の 寿命差はほとんどなく, 2 辺塗布品に比べて 4 辺塗布品が 高寿命になっている。また, Fig. 11に示した繰り返し曲げ と同様, 樹脂塗布品の寿命ばらつきが塗布無し品より大き くなっている。

衝撃曲げ試験を行った試験片のはんだ接続部の断線は Fig. 9 上同様に実装基板側で発生しており, 接続界面近傍 で破壊する場合や，はんだ母材内をき裂が進展して破壞す る場合が混在していた。

\section{4 温度サイクル試験結果}

$-40^{\circ} \mathrm{C} / 85^{\circ} \mathrm{C}$ の温度サイクル試験結果を Table 2 に示す。 表に示した数字は, サンプル数（5個）に対する累積断線 発生数である。弾性率が低い $\mathrm{A}$ 材の断線は 1800 回から発生 し始めており, B材の断線発生寿命より約 2 倍長くなって いる。樹脂塗布無し品は, 3000 回でも断線が発生していな い。樹脂塗布品の寿命は塗布無し品より短くなっており, 温度サイクルについてはアンダーフィル樹脂による補強効 果は得られていない。

Fig. 15 は, A 材 -2 辺塗布品で, $-55^{\circ} \mathrm{C} / 125^{\circ} \mathrm{C}$ の温度サイ クル試験中に連続的に測定したはんだ接続部抵抗と雾囲気 温度である。図中 $\mathrm{a}$ 点から, 高温保持中の抵抗值変動が始 まっており，回数を増すごとに抵抗值が増大している。低 温保持中の抵抗増加は高温より小さいことから, 高温保持 中に破壊が進行していることを示している。なお，この温 度サイクル試験での 2 辺塗布品の断線寿命は, $\mathrm{A}$ 材は 73, 120, 129 回, B材は 55, 69, 71 回となっており, A 材の寿命 が $\mathrm{B}$ 材より長くなる傾向は, 上記 $-40^{\circ} \mathrm{C} / 85^{\circ} \mathrm{C}$ の温度サイク ル試験結果と同じであるが，その寿命は $-40^{\circ} \mathrm{C} / 85^{\circ} \mathrm{C}$ に比べ て著しく短くなっている。A 材 4 辺塗布品の断線寿命は, 38,76, 113 回となっており, 塗布形状による顕著な差異は 認められない。

樹脂塗布による寿命向上効果が得られないのは, 樹脂の 線䐍張係数がはんだ材の約 2 倍と大きいことが原因であり, 温度条件が厳しい $-55^{\circ} \mathrm{C} / 125^{\circ} \mathrm{C}$ の試験でさらに寿命が短く なるのは, 温度サイクル試験の高温側温度が樹脂のガラス 転移温度に近づいたため, 線膨張係数もさらに大きくなっ たためと考えられる。

$-55^{\circ} \mathrm{C} / 125^{\circ} \mathrm{C}$ の温度サイクル試験を行った $\mathrm{A}$ 材 -2 辺塗布 品のはんだ接続部断面観察写真をFig. 16 に示す。観察した 断面は最外周に位置するバンプ列であり，そのうち Fig. 16

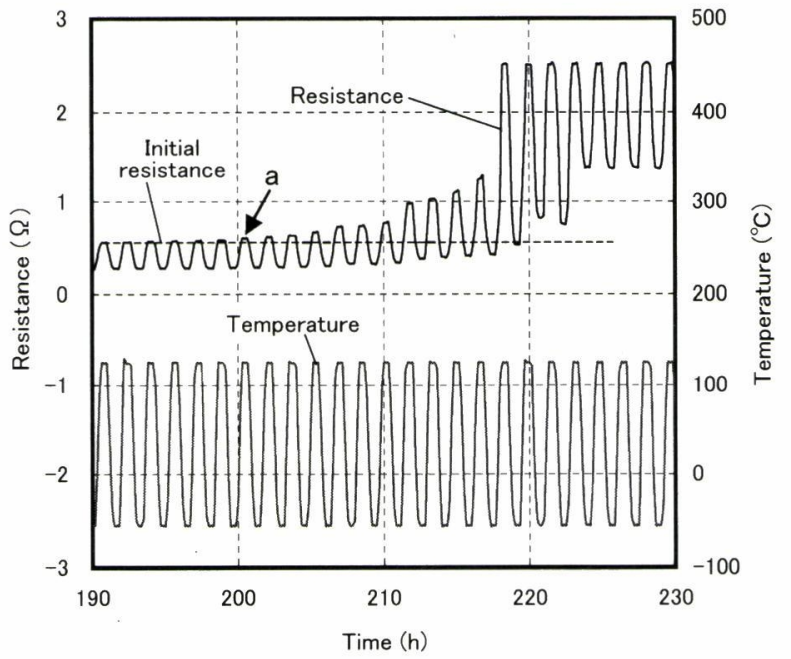

Fig. 15 Measurement results of resistance of solder joints on temperature cyclic test

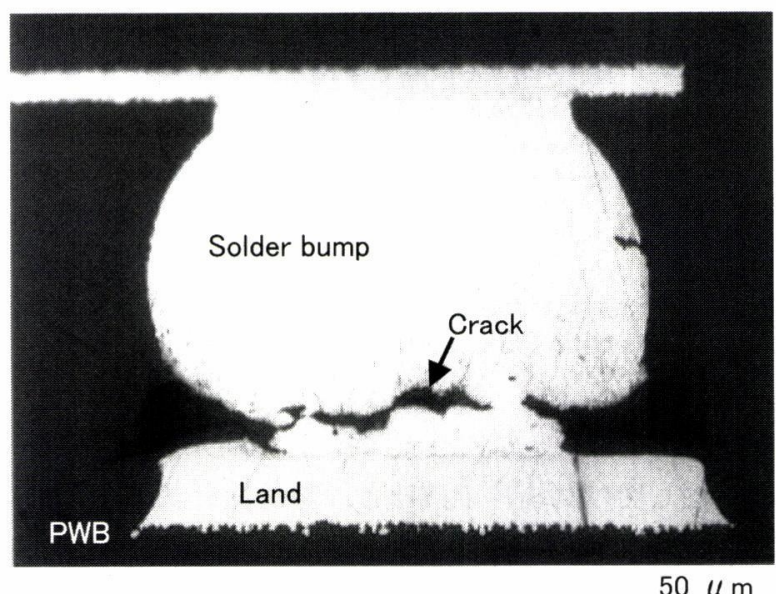

Fig. 16 Cross section of solder joint after temperature cyclic test

に示したバンプは，バンプ列の中央部分にあるバンプであ る。断線は実装基板側の接続部で, はんだ母材内で発生し ており，き裂が大きく開口している。断線が発生したバン プ周囲も含め, 外周部分でもアンダーフィル樹脂の割れは 見られなかった。なお，Fig. 16に示した破壊状態は，B材 でも同様であった。

\section{5 実験結果のまとめと考察}

アンダーフィル樹脂 $\mathrm{A}$ 材と $\mathrm{B}$ 材の機械的負荷に対するは んだ接続部の断線強度を比較すると, 静的曲げ強度は高弾 
性率のB材が高いが，繰り返し曲げおよび衝撃強度では $\mathrm{A}$ 材，B材には差異がない。アンダーフィル樹脂の樹脂割れ 強度は, 負荷速度が遅い場合の静的曲げは $\mathrm{B}$ 材が高くなっ ているが, 負荷速度が速い静的曲げや繰り返し曲げでは, $\mathrm{A}$ 材より低くなっていた。B材の負荷速度が速い場合の樹 脂割れ強度の低下は, 負荷速度上昇によって弾性率の高い $\mathrm{B}$ 材は $\mathrm{A}$ 材より塑性変形が生じにくくなり, 割れの起点で あるパッケージコーナー部のフィレット上端部の応力が増 大したためと考える。B材の繰り返し曲げ試験の樹脂割れ 強度が低下したのは, Fig. 8に示したB材の負荷速度依存 性のためであり, 樹脂割れ強度が低下したため, 繰り返し 曲げと衝撃曲げのはんだ接続部の断線強度がともに $\mathrm{A}$ 材と 同等になったと考えられる。この結果から, 高弾性アン ダーフィル樹脂による補強は, 衝撃のような高速負荷に対 しては補強効果が得られないことがわかる。樹脂を 4 辺に 塗布して大きなフィレットを形成すると, 静的曲げ，繰り 返し曲げおよび衝撃曲げいずれにおいても，樹脂割れ強度 とともにはんだ接続部の断線強度が増加した。大きなフィ レットを均一に形成すると, パッケージ搭載部の剛性が増 加し, 荷重制御型の負荷に対してはフィレットが小さい場 合よりパッケージ端部での基板変形量が減少する。これに よって樹脂割れ発生が抑制され, 機械的負荷に対する強度 が向上するものと考えられる。

これまで述べた実験結果やFig. 9 に示した断面観察結果 から，アンダーフィル樹脂を塗布したはんだ接続部の破壊 は, アンダーフィル樹脂の割れ発生に依存しており, 機械 的負荷に対する補強効果を向上するためには, 樹脂割れ発 生を抑制する実装構造の採用が必要である。樹脂割れは樹 脂の弾性率と伸びに依存すると考えられ，樹脂割れも考慮 した強度向上には, 樹脂弾性率の適正化と, 十分大きな フィレットをパッケージの 4 辺に形成する必要がある。樹 脂割れ発生後, すぐにはんだ接続部が断線しないのは, 樹 脂内をき裂が進展するために時間を要するのと, き裂がは んだ接続部に達しても, 複数のはんだバンプがき裂をピン 止めし, 進展を妨げるためと考えられる。樹脂塗布品の強 度ばらつきが塗布無し品より大きいのは, 樹脂の塗布形状 のばらつきによる発生応力の違いに加えて, 樹脂割れの進 展方向にもばらつきがあるためと考えられる。

温度サイクル試験でのアンダーフィル樹脂塗布品のはん だ接続部の断線は, 機械的負荷試験のようにパッケージ コーナー部バンプではなく, 中央部分のバンプに発生して いた。また, Fig. 15 に示した温度サイクル試験時の抵抗変 化において, 高温保持中の接続抵抗の増加が顕著であるの は, 高温時の樹脂の膨張によってはんだに破壊が生じたこ とを示している。したがって, 温度サイクル時の樹脂塗布 品の断線には, パッケージと実装基板の線膨張係数差によ るせん断変形よりも，はんだと樹脂の線膨張係数差による 垂直方向の変形が主に影響しているものと考えられる。B
材のように樹脂の弾性率が高いと, 樹脂自体の変形による 緩和量が少なくなり, 寿命が短くなる。したがって, アン ダーフィル樹脂実装品の温度サイクル寿命向上には, はん だ材との線膨張係数差を小さくする低熱膨張材と低弾性材 の使用が必要となる。

今回測定した実装試験片の強度と, 実際の使用環境で発 生する負荷とを比較し, 実負荷に対する強度のマージンを 検討した。静的に負荷が加わった場合に携带電話の実装基

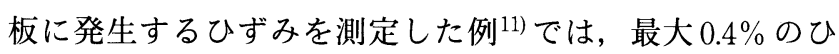
ずみ発生が報告されている。Fig. 6 に示した静的曲げ実験 結果では, 強度が低い $\mathrm{A}$ 材 -2 辺塗布品の樹脂割れ時の基 板ひずみは最小值でも約 $0.5 \%$ ，はんだ接続部の断線発生は 約 $0.8 \%$ であり, 実負荷以上となっている。また，携帯電 話を $1.5 \mathrm{~m}$ から LCD 面を下向きにした姿勢で落下させた場 合，実装基板には最大約 $0.09 \%$ のひずみが発生した報告 例12) がある。Fig. 14 に示した樹脂塗布品の衝撃曲げ試験結 果から, 上記基板ひずみが発生する衝撃負荷での寿命は 1000 回以上になると推定できる。ここで検討したのは, 実 使用環境での一部分の負荷例についてではあるが，今回検 討した樹脂による補強構造は, 携帯機器の実使用環境に十 分耐える強度であると考える。

\section{4. 有限要素解析による破壊挙動の検討}

\section{1 解析方法}

静的曲げ試験と衝撃曲げ試験を模擬した 3 次元モデルを 用いて有限要素法解析を行い，アンダーフィル樹脂表面応 力 $^{13)}$, はんだ相当塑性ひずみや実装基板の変形挙動などを 評価し, 機械的負荷に対するアンダーフィル実装時の破壊 挙動や補強効果を検討した。静的曲げ, 衝撃曲げいずれの 解析でも, アンダーフィル樹脂の表面応力や実装基板変形 を評価する場合は, はんだバンプは角型形状にモデル化し た。はんだバンプの相当塑性ひずみを評価する場合は, パッケージコーナーバンプのみ球状バンプでモデル化した。 モデルは 6 面体ソリッドの 2 次要素であり, 材料は基本的 に弾性体とみなし，はんだの相当塑性ひずみを評価する場 合のみはんだを弾塑性体とした。

解析に用いたパッケージ，実装基板 ${ }^{14)}$ おびはんだ15)の 材料定数を Table 3, Table 4 に示す。Table 3 に示した材料定 数のうち, 封止樹脂, インタポーザおよび実装基板はメー カカタログ値である。

\section{2 解析結果と検討}

2 辺塗布品のフィレットが小さい側の形状をモデル化し た樹脂塗布品に, Fig. 3 の衝撃曲げ試験による衝撃負荷を 加えた場合のアンダーフィル樹脂表面の最大主応力分布を Fig. 17 に示す。衝撃曲げ負荷の条件は, スパン $60 \mathrm{~mm}$, 落 下ロッド重量 $75 \mathrm{~g}$, 落下高さ $200 \mathrm{~mm}$ である。パッケージ コーナー部分に応力が集中しており, 樹脂割れの起点とよ く一致している。4辺塗布品のようなフィレットの大きな 
Table 3. Material properties of package and PWB

\begin{tabular}{l|c|c|c}
\hline Component & $\begin{array}{c}\text { Young's } \\
\text { Modulus } \\
\text { (MPa) }\end{array}$ & $\begin{array}{c}\text { Poisson's } \\
\text { Ratio }\end{array}$ & $\begin{array}{c}\text { Coefficient of } \\
\text { Thermal } \\
\text { Expansion } \\
\left(10^{-6} /^{\circ} \mathrm{C}\right)\end{array}$ \\
\hline Encapsulant & 21000 & 0.21 & 9 \\
\hline Chip & 190000 & 0.07 & 3 \\
\hline Interposer & 30000 & 0.16 & 13 \\
\hline $\begin{array}{c}\text { Printed Wiring } \\
\text { Board }\end{array}$ & 21000 & 0.16 & 15 \\
\hline
\end{tabular}

Table 4. Material properties of solder bump

\begin{tabular}{c|c|c|c|c|c}
\hline $\begin{array}{c}\text { Temperature } \\
\left({ }^{\circ} \mathrm{C}\right)\end{array}$ & $\begin{array}{c}\text { Young's } \\
\text { Modulus } \\
(\mathrm{MPa})\end{array}$ & $\begin{array}{c}\text { Poisson's } \\
\text { Ratio }\end{array}$ & $\begin{array}{c}\text { Yield } \\
\text { Stress } \\
(\mathrm{MPa})\end{array}$ & $\begin{array}{c}\text { Strain } \\
\text { Hardening } \\
\text { Exponent } \\
(\mathrm{MPa})\end{array}$ & $\begin{array}{c}\text { Coefficient of } \\
\text { Thermal } \\
\text { Expansion } \\
\left(10^{-6} /{ }^{\circ} \mathrm{C}\right)\end{array}$ \\
\hline-50 & 41300 & 0.3 & 48 & 1100 & 23.0 \\
\hline-15 & 40800 & 0.3 & 36 & 900 & 23.0 \\
\hline 27 & 38200 & 0.3 & 30 & 700 & 23.0 \\
\hline 75 & 35500 & 0.3 & 22 & 450 & 23.0 \\
\hline 125 & 33800 & 0.3 & 17 & 250 & 23.0 \\
\hline
\end{tabular}

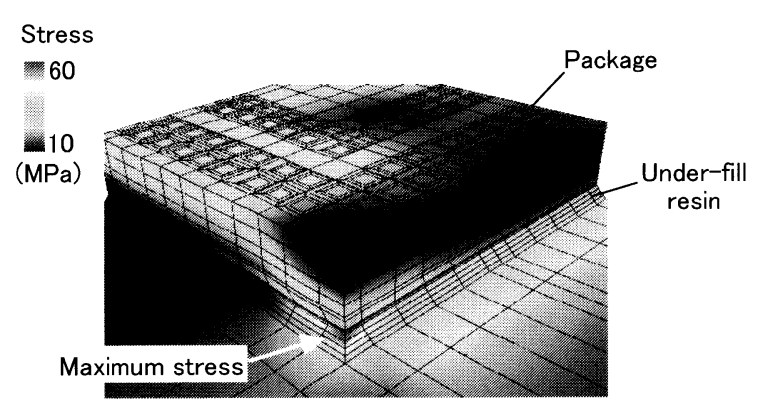

Fig. 17 Stress distribution of under-fill resin

モデルに上記衝撃負荷を加えた場合, 樹脂表面の応力は約 $1 / 2$ に減少した。このように解析においてもフィレットが小 さいと樹脂表面応力が増加する結果が得られており, 樹脂 割れの発生は加速されると考えられ，この傾向はFig. 12 の 結果と一致する。なお, フィレットの大小における樹脂表 面の応力の大小関係は, 静的曲げにおける解析でもほぼ同 じ傾向となった。

Fig. 18 は, 上記衝撃曲げ負荷での実装基板の板厚方向変 形状態をアンダーフィル樹脂塗布の有無で比較したもので ある。変形を評価した位置は実装基板の中心線上である。 塗布無しの場合は，はんだバンプが設けられているパッ ケージ外周部分の変形は小さいが, 中央部では変形が大き くなっている。一方, 樹脂塗布品の場合では, パッケージ 搭載部分はほぼ平坦となっており, 塗布無し品の場合より 変形量が小さくなっている。衝撃曲げのように荷重制御で 負荷が加わる場合は, パッケージ搭載部分の剛性を増加さ

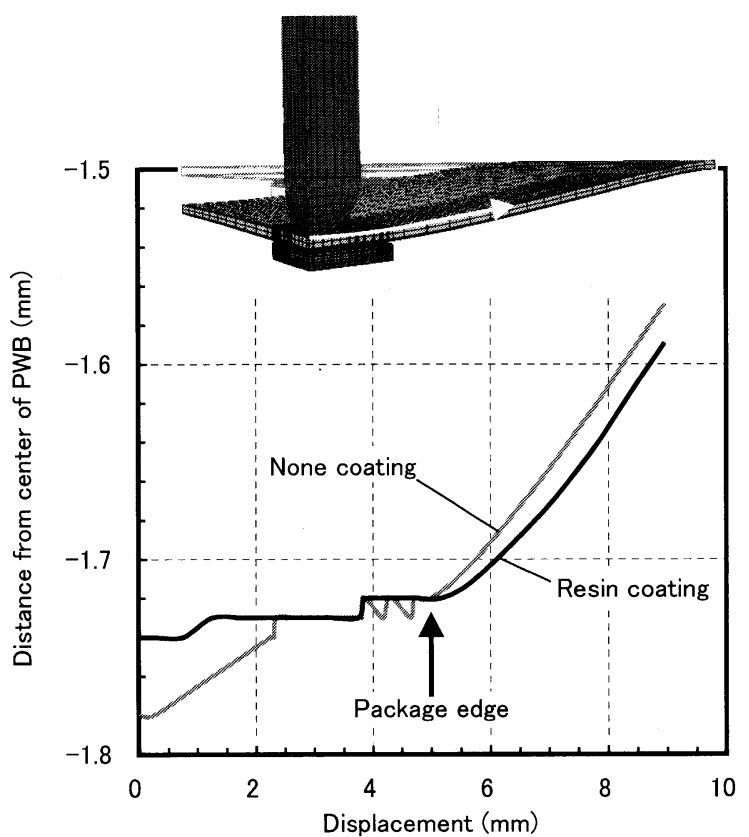

Fig. 18 Deformation behavior of PWB

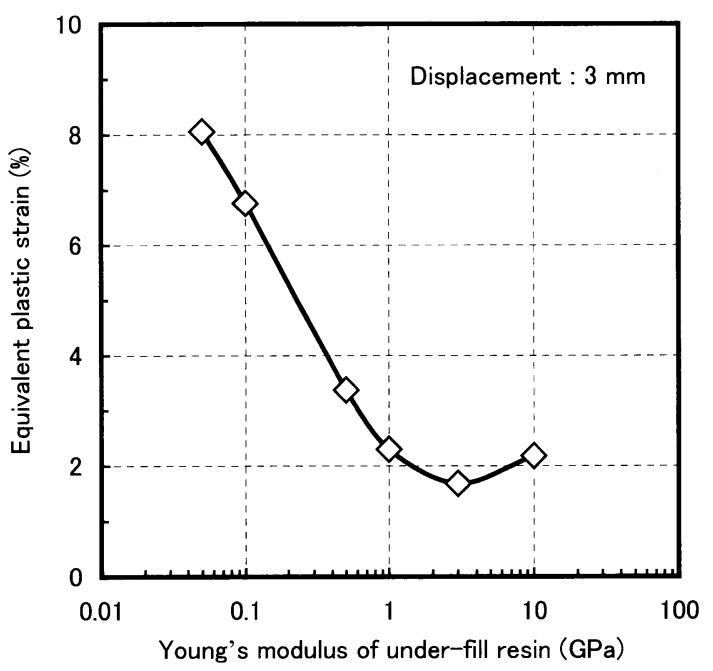

Fig. 19 Relationship between equivalent plastic strain and Young's modulus of under-fill resin

せて実装基板の面外変形量を低減するのが，はんだ接続部 の強度向上に有効である。アンダーフィル樹脂で補強する 場合, 大きなフィレットを 4 辺に形成すると, より高剛性 になるとともに，発生応力む小さくなり樹脂割れも抑制す ることができる。

Fig. 19 は，機械的負荷に対して補強効果を得るために最 適なアンダーフィル樹脂弾性率を検討するため, 静的曲げ 負荷時の樹脂弾性率とはんだバンプに発生する相当塑性ひ ずみの関係を求めた結果であり, フィレットの小さいモデ ルで，変位量を $3 \mathrm{~mm}$ 与えた場合の解析結果である。ひず みは樹脂弾性率が高くなると減少し, 弾性率が $3 \mathrm{GPa}$ 程度 で極小となった後は再び増加する。樹脂塗布無しの相当塑 性ひずみは $14.7 \%$ であり, 解析した樹脂弾性率の範囲では 
いずれも補強効果が得られている。機械的負荷が加わる場 合, 樹脂割れに伴ってはんだ接続部が断線するため, 実際 の破壊挙動とはモデルが異なるが，ひずみが小さい場合に 補強効果が大きいと仮定すると，弾性率の適正範囲は 1 10 GPa と言える。しかし，本研究で評価した弾性率 2.7 $\mathrm{GPa}$ の B材では負荷速度依存性が強く, 樹脂割れ発生強度 が低下する場合がある。したがって，機械的負荷に対して は樹脂弾性率を $2.7 \mathrm{GPa}$ 以下にする必要がある。

\section{5. 結 言}

アンダーフィル実装の構造適正化と設計技術確立のため, アンダーフィル樹脂をはんだ接続部に塗布した BGAパッ ケージ実装試験片について, 機械的負荷や温度サイクル負 荷に対するはんだ接続部強度を実験と有限要素解析で検討 した。得られた結論を以下に示す。

(1) アンダーフィル樹脂塗布によって, 静的曲げ, 繰り 返し曲げおよび衝撃曲げのはんだ接続部の断線強度は, 塗 布無しの場合より向上する。

(2) 樹脂塗布品では, はんだ接続部断線の前に樹脂割れ が発生する。弾性率が高い樹脂では, 樹脂割れの強度が塗 布無し品の断線強度より低下する場合がある。

（3）機械的負荷の強度向上には, 高弾性樹脂の使用や 4 辺フィレット形成によるパッケージ実装部分の剛性向上が 有効である。しかし, 高弾性樹脂は樹脂割れが発生しやす くなるので，剛性向上と樹脂割れを抑制できる樹脂材料の 選定が必要である。

（4）温度サイクル試験における信頼性向上のためには, アンダーフィル樹脂の低熱膨張化, 低弾性化が必要である。

(2004.5.14-受理)

\section{文献}

1）小川将志，村上里奈，住川雅人，松原浩司：“CSP用アン ダーフィルに関する研究”, 第 12 回マイクロエレクトロニ クスシンポジウム講演論文集, pp. 155-158, 2002

2) 加賀靖久, 于 強, 白鳥正樹：“アンダーフィル実装構造 のはんだ接合部における熱疲労信頼性評価”，日本機械学 会第 11 回計算力学講演会講演論文集, pp. 509-510, 1998

3) T. Burnette, Z. Johnson, T. Koschmieder and W. Oyler: "Underfilled BGAs for a Variety of Plastic BGA Package Types and the Impact on Board-Level Reliability", Proceedings of the 2001 Electronic Components and Technology Conference, pp.
1045-1051, 2001

4) T. R. Lindley: "BGA Solder Joint Reliability Study for Automotive Electronics", Proceedings of the 1995 International Conference on Multi Chip Modules, pp. 126-133, 1995

5) B. Vandevelde, E. Beyne, J. Van Puymbroeck and M. Heerman: "Thermal Fatigue Analysis of the Flip-Chip Assembly on the Polymer Stud Grid Array (PSGA) Package", Proceedings of the 1999 Electronic Components and Technology Conference, pp. 823-829, 1999

6) 矢口昭弘, 中村真人, 石川高司, 黒沢和仁, 木本良輔 : “携帯機器用アンダーフィル実装試験片の強度評価”，第 13 回マイクロエレクトロニクスシンポジウム講演論文集, pp. 376-379, 2003

7) 矢口昭弘, 山田宗博, 山本健一：“BGAはんだ接続部の衝 撃曲げ試験方法”，エレクトロニクス実装学会誌，Vol. 6, No. 4, 2003

8) 矢口昭弘, 山田宗博, 山本健一：“Pbフリーはんだ BGA 接 続部の衝撃信頼性設計技術”，エレクトロニクス実装学会 誌, Vol. 6, No. 7, 2003

9) 長埜浩太, 矢口昭弘, 山田宗博, 柴本正訓：“携帯機器用 CSP はんだ接続部の信頼性評価”, 日本機械学会 2002 年度 年次大会講演論文集 (VI), pp. 271-272, 2002

10) 田中直敬, 寺崎 健, 北野 誠, 春田 亮, 橋爪孝則 : “Fan-outタイプ CSP (Chip Scale Package)の構造信頼性設 計”，エレクトロニクス実装学会誌, Vol. 4, No. 6, 2001

11) 石川重雄, 長竹真美, 井門 修: “携帯電話開発へのシ ミュレーションの適用：FUJITSU, Vol. 51, No. 5, pp. 335340,2000

12) 井門 修, 舘野 正, 石川重雄, 伊東伸孝, 三代絹子 : “衝撃試験による歪評価”，日本機械学会 2002 年度年次大会 講演論文集(VI), pp. 255-256, 2002

13) J. Pyland, R. Pucha and S. Sitaraman: "Effect of Underfill on BGA Reliability", Proceedings of the 2001 Electronic Components and Technology Conference, pp. 85-90, 2001

14）矢口昭弘, 田中直敬, 安生一郎：“高信頼ファインピッチ BGAの構造設計”，エレクトロニクス実装学会誌, Vol. 4, No. 3, pp. 200-206, 2001

15）寺崎 健, 長埜浩太, 三浦英生, 中塚哲也：“周辺端子型 LSI パッケージにおける鉛フリーはんだ接合部の熱㾉労寿 命予測”, 7th Symp. Microjoining and Assem. Tech. in Electronics, pp. 441-446, 2001 